\title{
Thoughts on Aging
}

\author{
George Feher
}

Received: 7 December 2008/Published online: 13 November 2009

(C) The Author(s) 2009. This article is published with open access at Springerlink.com

When we, aging scientists, fade away and reach the category of "but what has he done lately", our consolation lies in our past students, post-docs and collaborators, who are now the torchbearers of science and about whom we think (justifiably or not) as having been positively influenced by us. Wolfgang Lubitz was one of my star post-docs. He spent the years 1983 and 1984 in our laboratory and has contributed so much to science since then. Moreover, Wolfgang not only remained a close colleague and collaborator, but he and his family became good friends of ours. I hope Wolfgang looks back to his post-doctoral experience at University of California, San Diego, as having been enjoyable and beneficial to his career.

When I was approached by Klaus Möbius to contribute a paper to Wolfgang's Festschrift on his 60th birthday, I was in a quandary. Although I still "kibbitz" on the activities of my ex-group, now led by Mel Okamura, my contributions do not warrant that I am a co-author on any of their publications and so I don't have a scientific paper to contribute. I therefore decided to contribute a non-scientific one from my collection of "Reminiscences and Ruminations" (G. Feher, unpubl.). The one "On Aging" seems to me most appropriate for the occasion.

\section{On Aging}

The only solution to aging is to die youngbut as late as possible.

The impetus of writing about aging came the other day after a visit to the urologist. No, don't worry, nothing serious really happened. I just went for a routine checkup to get my PSA (prostate specific antibody) evaluated. After waiting a

G. Feher (西)

Department of Physics, University of California, La Jolla, San Diego, CA 92093, USA

e-mail: gfeher@ucsd.edu 
while, I was finally called in by the nurse and given a consent form to sign. "What is this for?," I asked. "This is the permission to perform an endoscopic examination," she replied. "Why do I need that?" I inquired. "Because you have blood in your urine," she replied. "But I don't have blood in my urine," I protested. "Aren't you Mr. Felton?" she asked. "No, my name is Feher." "But I called out Mr. Felton," she said, annoyed. "Sorry, I must have misunderstood; I don't hear so well," I said sheepishly. Indeed, I had neglected to wear my hearing aid. At any rate it could have been worse if I hadn't inquired what I was asked to sign. (Incidentally, my PSA was OK.)

As for the hearing I was a long time in denial. I was hearing fine. I just couldn't make out what people were saying. I wished they would talk more clearly. When I finally realized that it might be my problem, I went to an otologist. He examined me and concluded that it was just a normal consequence of aging. But why do I hear worse with my right ear than with my left? After all, they are the same age. As a matter of fact, if my right ear continues to deteriorate at this rate, soon when my spouse whispers sweet nothings into it, that's exactly what I will hear; nothing. Besides hearing, the other senses, eyesight, smell and taste also, unfortunately, deteriorate with age. When a kind person told me that although I lost my eyesight, I have retained my vision, it was a poor consolation at best. And the common cliché: "Don't forget to smell the roses" is easier said than experienced.

When my father was in his eighties, he remarked to me: "They say that I have reached the golden years. Tell me Gyuri, where is the gold?" I had no answer to his question at the time. The answer recently dawned on me when I returned from the dentist. The gold is in the crowns!

Besides the physical deterioration, the decline of the mind can be far more serious. It includes impaired memory and cognitive ability. A ditty comes to mind (whose author's name I have long ago forgotten):

I am accustomed to my deafness

To my dentures I am resigned

I can mange my bifocals

But, oh, how I miss my mind.

A great deal of research has been and is being done on memory. I shall not enter into the results of this research; suffice it to say that there are two kinds of memories: short-term and long-term. It is the short-term memory that is usually affected in old age. How do we distinguish the relatively innocuous short-term memory loss from the more serious cognitive impairment? When you can't find your keys, that's a short-term memory loss. When you don't remember what keys are for, that's a serious cognitive problem. The short-term memory can be replaced by a pad and pencil but it is not a foolproof solution, you do have to remember where you put the pad. But the best strategy is to do things immediately and not put them off.

Let's lighten up this discussion with a few memory jokes:

The wife in her nineties to her husband of the same vintage: "Could you please go to the grocery store and buy strawberries and ice cream but, please 
write it down, you always forget things." "No, I won't forget," he replies. "OK, remember there are two things you have to bring," she tells him. The husband returns with a bag of bagels." "Bagels?!" she exclaims, "and where is the lox?"

Sam, age 90, to his physician: "Doctor, I have a serious problem. Last night at 3 a.m. I started to make love to my wife, Sarah. She protested and reminded me that I had made love to her at midnight." The physician's response to Sam: "But that's marvelous; I congratulate you on your virility." To which Sam replies: "But doctor, my memory, my memory!!"

Three old women sit at the table and complain about their memory loss. One says: "I look in the mirror and see I have a hat on. But I don't remember; am I going out or have I just returned?" The other woman complains: The other night I was sitting at the table with a plate in front of me and I don't remember; am I going to eat or have I just finished eating?" The third woman stayed silent and after some prodding, she said while knocking several times on the wooden table: "Thank goodness, I am ... come in!"

The doctor to his elderly patient: "I have bad news and good news for you. The bad news is that you have advanced Alzheimer's disease; the good news is that after a few minutes you won't remember it."

When I was young I dimly remember running after girls. But I can't remember what I wanted from them.

Oh memories, oh nostalgia (which isn't what it used to be!). Do you remember the good old days?

When particles were particles and waves were waves

When AIDS meant help and

GAY meant cheerful

When hardware meant hammer, screwdriver and pliers and

Time sharing meant togetherness and not computers and condos

A hard drive was a long grueling journey

Windows were for looking out

A chip was a piece of wood

A mouse pad was where mice hung out.

Gone are the days. But shouldn't we get some Brownie points for having been around for so long? Imagine we were around before TV, penicillin, polio shots, open-heart surgery, frozen food, space travel, Xerox, nylon, radar, fluorescent lights, credit cards, ball point pens, computers, fiber optics, cell phones, answering machines, microwave ovens, lasers, jet planes, a mind-boggling array of developments. I am sure I have left some out, so if you think of some more, please do contact me by e-mail or send a fax or leave a message on my answering machine or call me on my cell phone or ...

Let me leave now the memory lane and turn to cognitive deterioration. There can be many causes for this affliction, from the most serious one, Alzheimer's disease to 
more "normal" results of aging. It has also been shown that about half the patients that undergo open-heart surgery experience some postoperative permanent cognitive damage. Presumably small clots that are formed during surgery are dislodged and travel to the brain where they cause mini-strokes. Before my bypass surgery in 1990 a "thoughtful (or rather thoughtless) friend" brought me an article from the New York Times describing these grim statistics. Worried, I raised this point with my surgeon and anesthesiologist who after the operation teased me by dropping in several times a day, "How is your IQ today, Dr. Feher?"

What is the "normal" progression of mental deterioration with age? The most marked deterioration is the speed and accuracy with which information is processed. Although we usually don't quantify these developing deficiencies, we should not be surprised that they occur, since a quantification of physical deficiencies (e.g., the time to swim laps or walk a mile) clearly prove their existence. The popular homilies reflect this situation "In youth we learn, in old age we understand", or "In old age we are approximately right, in our youth we are precisely wrong". Creativity, that elusive gift whose origin is so difficult to pinpoint, also seems to decline with age, although there are many examples of creative old people. For example, Goethe completed "Faust" when he was eighty, Pablo Casals played the cello at 95. When asked why, he replied "I think I am still learning and making progress." Abraham moved at age 75 from Mesopotamia to Palestine and became the forefather of three great religions. And Winston Churchill in his old age made one of his typical "tongue in cheek" remarks "I love to learn, but I don't like to be taught."

So far I have talked about the external manifestations of old age. I want to turn now to our feelings and perception of old age. When do we become aware of it and what are our reactions to it.

When did I notice that old age was creeping up on me? It all started very gradually and subtly. When we first came to La Jolla in the 1960s, the cashier at the cafeteria (University of California, San Diego) still asked me "student or faculty?" (student meals were subsidized). They soon stopped asking. When I was in my sixties, the cashier at the movies occasionally asked me for my driver's license to verify that I qualified for a senior discount. They too stopped asking years ago. When people started to tell me how well I looked, I started to get suspicious. I felt I had passed all the other stages of life: infancy, childhood, adolescence, middle age and had reached the final one "Oh, you look so well." But what really shook me up happened a few years ago when I arrived at the waiting room of the airport and a young lady stood up and offered me her seat. This was followed shortly afterwards by another embarrassing incident. I was standing on the curb daydreaming while waiting for the lights to change. Suddenly I heard a voice next to me: "May I help you across the street?" More recently I am asked at the checkout of the grocery store: "May I help you with the groceries to the car?" And there are the occasional "senior moments" (I hate that phrase!) that you would rather forget about. You open the mail in your outbox and put shaving cream by mistake on your toothbrush. And when you hear a ring you are not sure whether it is the door bell, the telephone or just the ringing in your ears. And contrary to my knowledge of physics, gravity seems to be getting stronger with time. But relax, you are not alone with these dilemmas. Recently a friend of mine in his eighties confided that when he tried to 
change the oil in his car he couldn't figure out how to activate the hood release. And he complained that his back goes out more often than he does and said how glad he was the other day when he stepped out of the shower and the mirror was fogged up. Oh, and did I tell you that when they lit the candles on my last birthday cake, the fire alarm went off?

How do we cope with the inexorable aging process? How do our attitudes change with age?

A good characterization of old age is "grayness," not only of our hair but of our attitudes and opinions. When we were young all issues seemed to us black and white. We thought we knew everything and had all the answers. It is ironic that as we age and acquire more and more knowledge and experience, we become more and more aware of our ignorance. We become aware of the many facets and complexities of the issues. The solutions are not as simple as they used to be; the black and white turns into grayness. It reminds me of the story of the old man who was asked to arbitrate between two neighbors. The problem was a branch of a fruit tree that extended to the neighbor's property. Who was entitled to the fruit of the overreaching branch? One of them argued that since the roots of the tree are on his soil, the fruit belongs to him. "You are right" said the old man. The other man argued that since the branches profit from the sun shining on his property, the fruits of that branch belong to him. "You are right" said the old man. "But both cannot be right," protested a bystander who witnessed the scene. "You are also right," answered the old man.

This "seeing all the angles" approach, mature and wise as it seems, results in a certain heaviness and lack of spontaneity, which I believe contributes, in the sciences at least, to reduced creativity. Not enough opportunities are given to accidental, serendipitous discoveries. Many an older researcher has talked himself out of a promising experiment that was successfully pursued by a less critical younger investigator.

An important change with age is a shift in priorities. Time, which had been our most precious commodity, has been delegated to a secondary place. Similarly, the accumulation of worldly possessions becomes of little interest. As a result we may seem to be more generous, but what really happened is that giving no longer represents a sacrifice; it does not cost us much, so to speak. We also look more and more at our past and we refrain from making long-range plans for the future. I call it the "green banana" effect; we don't buy green bananas since we don't know whether we will be around when they ripen. Family and close friends become increasingly more important and we lose interest in acquaintances, particularly the ones that bore or annoy us. They are put "under the bar" and we ignore them together with the many daily annoyances that used to bother us. (It is getting quite crowded under the bar).

With age we undoubtedly lose some degree of interest in what is going on around us. But we should not lose the capacity to care. It is not death that we should be afraid of, but death of feelings and awareness. The two characteristics that actually improve with age, emotional intelligence and interpersonal social cognition, help us in overcoming that danger. And finally, we should be ready to replace our past ambition to stand high in the world by a loftier one: to stoop down and help others up. 
The last few paragraphs are a bit sad, negative and heavy, so let me brighten them up with a list of the advantages of old age:

You can say "When I was your age..." to more and more people.

You probably will be among the first hostages released.

You no longer care what people think, you can be yourself and do what you want.

You feel comfortable being kind rather than being right.

You have seen it all before, even if you don't remember where and when.

You get a discount in movies and on public transportation.

You change the things that can be changed, accept those that cannot and most important, you have acquired the wisdom to know the difference.

You have come to realize that enjoying the journey is as important as reaching the destination.

It is the perfect time to look inward, outward, backward, forward and-upward.

I want to finish this essay with the translation (my wife Elsa and myself) of a poem written in German by Dr. Dan Bustan in 1935 in Tel Aviv.

To present this poem makes me fearful

because it certainly is not cheerful.

But the alternative to getting old

Is-I fear to say-eternal cold

It is your fault for reaching eighty

your wish to live, your trust in Deity.

It took a lot of will and patience,

a sturdy heart and medications.

About your age you cannot lie,

of age itself you do not die.

But the infirmities it brings

will spoil your moods and other things.

You may look better than you feel,

yet this is neither consolation nor a big deal.

With aching back, stiff legs and knees

you encounter a contemporary who hardly sees

He looks at you but does not greet

and to hear what you say is a big feat.

Your grey matter shrinks in the brain,

a condition that to everyone is plain.

You write everything down on paper scraps you lose:

Your memory's gone, no longer of use.

You hunt for names and words,

that important address,

which, once you've retrieved it,

you've promptly forgotten, to your distress. 
"Where is my watch?" You tear your hair.

Perhaps stolen? Oh dear, beware!

You find it soon, for you yourself

had put it on the bathroom shelf.

The keys! Who can be blamed? For

they are stuck outside the door.

They were stuck throughout the night, evidence of your old-age plight.

One moves about devoid of feeling

but on occasion hits the ceiling.

That is really of no use,

better to remain happy and loose

One just gets stooped, stupid and slow

but how can one prevent this natural flow?

It is sad one can't become

immune to this outcome.

But, friend, you can't complain;

You've turned 80 and YOU're to blame.

I know, Wolfgang, that at age 60 you are still a "spring chicken" blossoming in the prime of your career and so some of the above remarks won't resonate with you-yet. But please, keep the essay, re-read it every few decades and you will be able to identify more and more with the foibles of aging. In the meantime, rejoice in your youthful and mature status. I wish you many more productive years and health and happiness to you and your family.

Open Access This article is distributed under the terms of the Creative Commons Attribution Noncommercial License which permits any noncommercial use, distribution, and reproduction in any medium, provided the original author(s) and source are credited. 